УДК $821.111(73)-311.1 .09$

DOI: https://doi.org/10.51209/platform.1.3.2021.166-192

Іван Вікторович БРАТУСЬ,

кандидат філологічних наук, доцент, Київський університет імені Бориса Грінченка,

Київ, Україна, e-mail: kulturolog@gmail.com, ORCID: 0000-0002-8747-2611

\title{
КУЛЬТУРНО-ІСТОРИЧНИЙ КОНТЕКСТ ПОДОЛАННЯ ТРАВМАТИЧНОГО МИНУЛОГО (НА ПРИКЛАДІ РОМАНУ СОЛА БЕЛЛОУ «ПЛАНЕТА МІСТЕРА СЕММЛЕРА»)
}

\begin{abstract}
Анотація. У статті проаналізовано культурноісторичний контекст роману видатного американського письменника Сола Беллоу. У дослідженні розглядається питання подолання травматичного досвіду головним героєм твору, його намагання позбутися негативних наслідків травми на свідомість i почасти підсвідомість. Увага надається також віковій специфіці головного героя, що відтворює особливості людей похилого віку. Окремо ставиться питання особистої відповідальності за правильність морального вибору в екстремальних життєвих умовах. Особлива увага надається періоду Другої світової війни в розрізі травматичних споминів та неспроможності людської психіки засвоїти злочинну природу жахливих подій тієї доби. Також у фокусі дослідження опиняється адаптація людей, що пережили Голокост, в американському суспільстві загалом та в Нью-Йорку зокрема. Актуальність дослідження обумовлена невирішеністю численних проблем історичної пам'яті, необхідністю поглиблювати та розширювати знання щодо травматичної пам'яті та шляхів подолання негативних наслідків. Наводяться приклади несвободи від травматичного минулого, загального


меморіального дискурсу, динаміки індивідуальної та колективної пам'яті, моралізації історії та актуалізації систем проти повзучого універсального забуття. Автор зупиняється на проблемах смерті, військового минулого, Голокосту тощо. Доведено, що в романі Сола Беллоу «Планета містера Семмлера» значне місце посідає аналіз національної ідентичності в історико-культурному контексті XX ст. Виконаний огляд основних подій біографії Артура Семмлера 3 точки зори травматичної пам'яті, що невідступно переслідує головного героя. Окремо аналізується історико-культурний контекст американської дійсності II пол. XX ст. загалом і «життя Нью-Йорку» зокрема. Надається відповідна оцінка подій нью-йоркського життя в якості «відволікаючих факторів» в подолання травматичної пам'яті. Наведено баланс між пам'яттю та забуттям, переконливі аргументи на користь правдивого конструювання минулого з позиції жертви, що, відповідно, потребує збереження слідів нацистських злочинів заради послаблення руйнівної сили забуття на особистість жертв. Перемога вбачається в артикуляції травмованої пам'яті, виводі іiі 3 «непрозорого ядра» (підсвідомості). При цьому відстоюється позиція Артура Семмлера в боротьбі проти «систематичної брехні».

Ключові слова: Сол Беллоу, американська література, війна, травматична пам'ять

Вступ. Відчуття минулого, що тисне на свідомість, часто не покидає людей із трагічним досвідом. «Вічне сьогодні» ніколи не може звільнитися у багатьох від жахливих переживань минулих років, коли людина опинялася в скрутних обставинах, під тиском яких формувався неповторний травматичний досвід.

Постановка проблеми. У статті буде розглянуто подолання травматичного минулого на прикладі роману Сола Беллоу «Планета містера Семмлера» («Mr. Sammler's Planet», 1970 р.) у широкому культурно-історичному контексті. Безумовно, що особистий досвід кожного $є$ унікальним, але основні загальні риси переживання та подолання психологічних 
ран надають нам можливість використовувати наявний матеріал для узагальнюючих роздумів, що майстерно вплетені в художню тканину твору. Більше того, механізми індивідуальної та колективної пам'яті дуже різняться (дехто вважає колективну пам'ять взагалі «не зовсім пам'яттю», оскільки вона $\epsilon$ конструктом геть іншого гатунку [6]). Тим не менш, Сол Беллоу майстерно вписує індивідуальні спогади головного героя в тканину подій XX ст., що дозволяє відстежити шляхи взаємодії людини та соціуму.

Друга світова війна значно поглибила наші знання про «людське зло», про те, «на що здатне людство» в цілому й окремі його представники зокрема. На межі історичної правди Сол Беллоу експериментує з гірким досвідом «жертв війни», що гордо несуть звання «тих, хто вижив». Серед метушливого ньюйоркського життя величаво зображені ці «залишки людей», що всі зранені болісним досвідом. Ці люди не здатні органічно інтегруватися в суспільство, залишаються живими свідками злочинів нацизму та водночас страждають від власної непристосованості.

Та життєві колізії не тільки поглиблюють відчуття непристосованості - вони становлять собою матеріал подолання травматичного досвіду, допомагають відволіктись від трагічного минулого та вибудувати більш-менш прийнятне «майбутнє». Саме аналізу цих факторів присвячена стаття.

Аналіз останніх досліджень і публікацій. Творчість Сола Беллоу вважалася класичною ще за його життя. І сьогодні йому присвяченні значні за кількістю та якістю дослідження. Високоінтелектуальний рівень творів письменника дозволяє дослідникам заглиблюватися навіть у доволі вузькі рамки постановки проблеми.

Так, у деяких дослідженнях професор Марина Карпівна Бронич вивчає зв'язок творчості Сола Беллоу та Льва Толстого [3]. Примітно, що дослідниця вказує: «Сол Беллоу належить до того типу письменників, що в своїй творчості свідомо орієнтуються на досвід попередників і сучасників» [3, с.174]. У романі «Планета містера Семмлера» творчість Толстого прямо 
інтегрується в тканину твору. Зокрема, Семмлер порівнює себе 3 літературним героєм (П’єром Безуховим) Льва Толстого i визнає, що 3 ним не сталося «таке диво»: «Oh, it probably happens from time to time. Pierre Bezukhov was altogether lucky. Of course he was a person in a book. And of course life is a kind of luck, for the individual. Very booklike. But Pierre was exceptionally lucky to catch the eye of his executioner. I myself never knew it to work. No, I never saw it happen. It is a thing worth praying for. And it is based on something. It's not sin arbitrary idea. It's based on the belief that there is thesame truth in the heart of every human being, or a splash of God's own spirit, and that this is the richest thing we phare in common. And up to a point I would agree. But though it's not an arbitrary idea, I wouldn't count on it» [6, p.189].

Українська дослідниця Олена Олександрівна Механікова в своїх розвідках аналізує жанрові особливості романів Сола Беллоу. Вона виходить із того, що «Оскільки центральною темою для С. Беллоу є проблема деформації свідомості в умовах існування в соціумі, а причини втрати людиною ідентичності він схильний пов'язувати з недосконалістю і несправедливістю суспільного устрою, на передній план виступає криза ідентичності як результат конфлікту між людиною i суспільством» [4, с.194].

Алан Маршал [8] концентровано проводить аналіз розрізнених виявів Артура Семмлера - акцентується на його англофільській позиції. При цьому дослідник влучно підмічає, що головний герой не ідеальний, і його вищою «мудрістю» $\epsilon$ «тримати язик за зубами». Наводяться аргументи за та проти «банальності зла», що була озвучена Ханною Арендт. Дослідження побудоване на перетині літературних, філософських та історичних матеріалів Ханни Арендт, Сола Беллоу, Мартіна Гайдеггера, Сократа, Льва Толстого та інших. Дослідник приходить невтішних висновків про нездатність людства позбавитись негативних нашарувань минулого (зокрема Другої світової війни). Нацизм відкрив шлях надзвичайному рівню насильства, що могло бути зупинене тільки переродженими за новими/старими законами 
особистостями - єдине не вибите око Артур Семмлер використовує «за призначенням». I це «призначення» прицілитися в німецького солдата. Алан Маршал підкреслює, що подібний рівень досягнутий у відповідь на «поховання живцем» і тиском травми від пережитих страждань.

Аллен Гуттманн [8] здійснив дослідження роману «Планета містера Семмлера» ще в 1973 р. - невдовзі після появи самого твору. Відповідно до культурно-історичного контексту того часу ми можемо ознайомитися 3 високодеталізованими обставинами написання роману та особливо на першу реакцію від нього в західному суспільстві. Дослідник наполягає на розрізненні Сола Беллоу (автора) та Артура Семмлера (головного героя), оскільки вони мають як спільні, так і відмінні риси. При різності емігрантського досвіду, різності часових проміжків XX ст. та інших подібних спостережень, Аллен Гуттманн виводить основну відмінність - Артур Семмлер пережив травматичний досвід Голокосту, а Сол Беллоу тільки описує цей стан. У цьому принципова різниця (що не так проглядалася в попередніх і подальших літературних паралелях (Аса Левенталь, Огі Марч, Мозес Герцог, Чарлі Сітріним, Чак). При цьому Аллен Гуттманн порівнює Артура Семмлера та Мозеса Герцога в аспекті видозмін деяких аспектів трансформації особистості. Порівнювати Семмлера зі Сітріним і Чаком автор статті не міг у цій публікації - твори «Дар Гумбольдта» («Humboldt's Gift») та «Равельштайн» («Ravelstein») побачать світ пізніше. Але саме в Артурі Семмлері глибина жорстокості головного героя досягла свого апогею у Сола Беллоу, в прірву між високим інтелектом i вбивством провалилися цілі пласти «цивілізаційних досліджень».

У статті також дослідженні деякі культурно-історичні контекстуальні аспекти життя та творчості Сола Беллоу. Його творчість аналізується в контексті літератури II пол. ХХ ст. [1]. Приділено увагу передусім відчуттю хиткості людини в буремному світі, кафкіанській відчуженості творів Сола Беллоу та тиску зовнішніх обставин (що часто призводить до 
деформації та руйнації особистості). Безпосередньо роман «Планета містера Семмлера» порівнюється 3 романом Юрія Трифонова «Старий» [2]. У дослідженні зроблено висновок, що «автори намагалися довести суттєвий вплив історії на теперішнє. Хоча сам вплив і був беззаперечний, але залишалися невирішеними проблеми тонких психологічних механізмів опанування історичного матеріалу. Саме за допомогою художнього узагальнення письменникам вповні вдалося передати мінливий характер спогадів [2, с.451].

Мета статті - проаналізувати шляхи долання травматичного досвіду на матеріалі роману Сола Беллоу «Планета містера Семмлера».

Виклад основного матеріалу. Роман «Планета містера Семмлера» просякнутий водночас надією та безнадією. Письменник намагається освітити шлях у мороці повсякденних проблем, що не можуть принести жодного дієвого рішення «жертвам війни». Саме неможливість «переварити смерть» призводить у творі часто до парадоксальних тверджень. Сол Беллоу швидше орієнтується на «відсутність світла» як стан припустимого морального комфорту в процесі особистого переосмислення. Подібна «чесність» зустрічається в поезії Інокентія Анненського:

Среди миров, в мерцании светил

Одной Звезды я повторяю имя...

Не потому, чтоб я Её любил, А потому, что я томлюсь с другими.

И если мне сомненье тяжело, Я у Неё одной ищу ответа, Не потому, что от Неё светло, А потому, что с Ней не надо света.

Самі герої роману мають різний досвід усвідомлення дійсності в залежності від умовної «печатки війни в невидимому паспорті». Ця печатка вирізняє «ветеранів», дітей війни та 
в'язнів концтаборів 3-поміж інших мешканців Нью-Йорку вони понівечені травматичним досвідом найкривавішої війни $\mathrm{XX}$ ст. Сол Беллоу схожий на лікаря - він аналізує проблеми без зайвих застережень, у його письменницькому арсеналі знаходяться вражаючі фарби для відтворення надлюдського надлому в жертвах війни. Цим він додатково виносить моральний вирок нацизму, що призвів до подібних скалічених людських доль.

Центральне місце в оповіді посідає Артур Семмлер його роздуми та дії викладені в романі найширше. Його нормальність та впорядковане життя виступає екзотичним контрастом до «божевільного міста». За більш ніж сімдесят років життя Артур Семмлер багато бачив, пережив чимало болючих втрат і намагається перманентно налагодити стосунки 3 людьми, що оточують його, гідно провести залишок життя.

Ключем до розуміння головного герою роману виступає його «воскресіння» - він був розстріляний i «похований живцем» разом із дружиною та десятками інших, але єдиний дивом вцілив під час екзекуції. Фактично йдеться про нестійкий стан між життям і смертю, що не полишає виживших, - цей унікальний досвід міцно сплітає антагоністичні за своєю сутністю стани буття та небуття. Саме сплав переживань у культурно-історичному контексті спогадів породжує своєрідні конструкти, що інколи втілюються в самобутні літературні твори. Одним із кращих взірців ми можемо вважати вірш Олександра Твардовського (наводимо фрагмент):

Я убит подо Ржевом, В безыменном болоте, В пятой роте, на левом,

При жестоком налете.

Я - где корни слепые

Ищут корма во тьме;

Я - где с облачком пыли

Ходит рожь на холме; 
Я - где крик петушиный

На заре по росе;

Я - где ваши машины

Воздух рвут на шоссе;

Где травинку к травинке

Речка травы прядет, -

Там, куда на поминки

Даже мать не придет.

Летом, в сорок втором,

Я зарыт без могилы.

Всем, что было потом,

Смерть меня обделила.

Цей вірш $є$ художнім узагальненням концептуального розуміння війни як невідворотної смерті. Фактично неможливо «обдурити війну» - вона настільки в'їдається у свідомість людини (яка потрапляє в іiі поле діï), що навіть біологічне виживання лише підкреслює «мертвість» природи жахливої «м'ясорубки». У Сола Беллоу Артур Семмлер сам себе позиціонує у буремні роки як «не зовсім людину». Виклики світової катастрофи пробудили в головного героя майже тваринні інстинкти, пропустили його крізь жорнова граничних випробувань та здійснили в ньому колосальну трансформацію духу, що ніби втратила актуальність із закінченням бойових дій. Ці виклики запустили в особистості незворотні процеси, що мають здебільшого деструктивний характер. При цьому подібні перевтілення спричиняють до якісного прориву у боротьбі 3 нацизмом - Артур Семмлер став одним із переможців над нацизмом, не дав ворожим силам завершити свої канібальські задуми. Парадокс полягає в тому, що, втративши деякі елементи людяності, Семмлер власне і відстояв людяність у глобальному масштабі.

Травматичний досвід Семмлера хитається між пам'яттю та забуттям. Сол Беллоу занурює читача в каскади хаотичних 
роздумів, що марно намагаються поєднати «старий світ» до війни, війну та повоєнне життя. Артур Семмлер постійно тяжіє до «ідеалів минулого», намагається впорядкувати фонтануюче життя в Нью-Йорку та віднайти можливість наповнити змістом останні роки життя. Усі ці спроби виявляються невдалими хаос, образи та абсурдність супроводжують головного героя протягом всього роману. Та постійне емоційне подразнення та невідповідності не здатні зламати міцний внутрішній стрижень.

Найбільший травматичний вплив на свідомість, як правило, пов'язують зі смертю - вона знаходиться внизу «моторошної долини» (англійською - uncanny valley) сприйняття людини. Для Семмлера ця тема така само болюча, хоча життєві випробування могли притупити його почуття. Та Сол Беллоу тільки підкреслює серйозне ставлення Семмлера до смерті. Головний герой вважає, що тільки мерців варто сприймати серйозно, оскільки вони не здатні змінитися.

Фаталізм травми Сол Беллоу приписує незбагненним за своєю ницістю та нестандартним за методологією законам буття - людство ніби перед ними «закрило двері». Сам Семмлер опинився в ситуації, коли «смерть не підняла слухавку». Саме пережита травма дозволяє головному герою абстрагуватися від тіней смерті, що постійно його переслідують. Потужний інтелект не зданий «переварити» містичні образи минулого, але Семмлер постійно шукає аналогії в історії, здійснює аналітичний аналіз консолідованого філософсько-релігійного досвіду людства.

Сам Семмлер вбивав німецьких солдат і мав досвід у цій царині. Але цей досвід став вже набутком історії. Про це чудово описав поет Юрій Левитанський:

Ну что с того, что я там был.

Я был давно. Я всё забыл.

Не помню дней. Не помню дат.

Ни тех форсированных рек.

Я неопознанный солдат.

Я рядовой. Я имярек. 
Я меткой пули недолёт.

Я лёд кровавый в январе.

Я прочно впаян в этот лёд -

я в нём, как мушка в янтаре.

Но что с того, что я там был.

Я все избыл. Я всё забыл.

Не помню дат. Не помню дней.

Названий вспомнить не могу.

Я это всё почти забыл.

Я это всё хочу забыть.

Я не участвую в войне -

она участвует во мне.

И отблеск Вечного огня

дрожит на скулах у меня.

Уже меня не исключить

из этих лет, из той войны.

Уже меня не излечить

от той зимы, от тех снегов.

И с той землёй, и с той зимой

уже меня не разлучить, до тех снегов, где вам уже моих следов не различить.

Семмлер висловлює бажання забути «вистріл у голову». Але цей пункт пам'яті неможливо викреслити. Він не може забути ні те, як стріляли в нього, ні як стріляв він. Травма смерті трохи загоюється постійними спостереженнями за оточуючим світом - це допомагає Семмлеру абстрагуватися від похмурих думок. При цьому він примирився з невідворотністю минулого його не можна змінити. Конструкт пам'яті Семмлера не губить живий зв'язок із подіями війни - він не вдається до маніпуляцій. За допомогою абстрагування американською дійсністю Семмлер просто намагається змістити баланс між «свободою пам'ятати» $\mathrm{i}$ «підсвідомою приреченістю пам'ятати» в площину повсякденної метушні. Та динаміка спогадів завжди відповідає 
найвищій кульмінації - смерті. Семмлер ніби змирився 3 подібним станом речей.

Головний герой аналізує різні варіації помирання. Наприклад, він аналізує те, що голод притуплює відчуття i пом'якшує горе: «Even starving mothers could not feel for more than a day or two the children torn from them. Hunger pains put out grief» [6, p.233]. Подібний фактаж Семмлер пережив на власному досвіді і не може спокійно дивитися навіть на кістки, що їдять пацюки на вулицях Нью-Йорка, - він наполегливо згадує, що й сам був радий таким об'їдкам під час війни.

Подібні історико-культурні паралелі допомагали Семмлеру бачити «правду життя» без прикрас. Смерть чатувала його в багатьох іпостасях, навіть цілковито несподіваних. Зокрема він пригадував, що переховувався не від німецькофашистських військ, а від своїх вчорашніх побратимів по зброї: «When Mr. Sammler hid later in the mausoleum, it was not from the Germans but from the Poles. In Zamosht Forest the Polish partisans turned on the Jewish fighters. The war was ending, the Russians advancing, and the decision seems to have been taken to reconstruct a Jewless Poland. There was therefore a massacre» [6, p.140]. Тобто відбувається в пам'яті Семмлера наявний феномен палімпсесту.

Разом із тим, Семмлер намагається зберегти об'єктивність. Його життя ввібрало й відчуття вдячності полякам за власний порятунок (поляк переховував його) i порятунок доньки (монахині переховували ії в монастирі):

«"-Conquered people tend to be witty."

"-You don't like Poles very much, Uncle."

"-I think on the whole I like them better than, they liked me. Besides, a Pan once saved my life."

"-And Shula in the convent."

"-Yes, that too. Nuns hid her"» [6, p.98].

Бачення смерті рідних, тим не менше, назавжди пошкодило психіку Семмлера, змістило всі прийнятні для нього маркери людяності. Він розумом пам'ятав себе, коли він, будучи дитиною, прикривав долонею служниці свій ротик при чиханні. Він пригадував інтелектуальні бесіди в Англії та тисячі 
прочитаних книжок. Але, як було зазначено вище, тільки мертвих він став здатний сприймати «серйозно».

Водночас смерть не зробила Семмлера циніком - він вболіває за темношкірого, коли крадій отримує пошкодження від колишнього зятя Семмлера, ветерана Другої світової, героя Сталінграду Ейзена. Зять пояснює, що надміцний чорношкірий крадій повинен отримати важкі травми для нейтралізації, але Семмлер не погоджується «довести до кінця» бійку, намагається iii зупинити. При цьому він сам зазнав від темношкірого чудернацьке приниження (Семмлер намагається тлумачити символічно брутальну витівку крадія).

Навіть смерть племінника Семмлер використовує 3 позицій пошуку ключа до розуміння круговерті всесвіту. Саме 3 смертю племінника пов'язане також матеріальне становище Семмлера та його доньки. Сол Беллоу припускається в сюжеті окремої лінії про «гроші мафії» - Шула знаходить їх, i вони стають забезпеченими до кінця життя. Але Семмлер вже приміряє на себе звичний образ живого мерця - він аналізує вчинок племінника 3 вигадкою про «аналізи» як вияв високої людяності. Адже його племінник подбав, щоб рідні не бачили його відходу, - він попросив знайомих лікарів відвести його ніби «на аналізи», де він помер. Артур Семмлер навчився цінувати саме такі вияви логіки смерті - вона не обтяжує оточуючих трагізмом неминучості. Травматичний досвід трансформувався у всеосяжну концепцію «зрозуміти i вибачити».

Питання старості дуже важливе для розуміння головного герою роману. Сол Беллоу відходить від шаблонного зображення старого мудреця чи від притчивості хемінгуеївського старого. Хоча Сол Беллоу не уникає спокуси надати своєму герою певних символічних рис - наприклад, він одним здоровим оком «бачить більше, ніж більшість двома».

Лейтмотивом старіння Артура Семмлера $є$ розуміння неможливості «піти вчасно»: «And of course no one knew when to quit. No one made sober decent terms with death» $[6, \mathrm{p} .8]$. Найтравматичнішою $є$ дія старості у відриві від природного 
культурно-історичного середовища Семмлера - він відчуває себе «уламком минулого». Сол Беллоу деякі моменти старіння зображає комічно - як Семмлер слідкує за темношкірим крадієм, деякі моменти сповненні драматизму - вболівання за майбутне психічно хворої доньки, деякі трагічно - коли Семмлер раптово бачить себе усамітненим серед «сучасниківмерців».

Фізіологія старіння Солом Беллоу продемонстрована 3 разючою відвертістю - Семмлер справляє малу нужду в умивальник, в теплі періоди «від нього трохи тхне» тощо. Ще відвертішою є оповідь про старіння двоюрідного брата Марго Уолтера Брука, старість якого супроводжувалася серйозними психічними розладами. Семмлер розумів причини подібних травм - здебільшого це було відлунням ув'язнення Уолтера Брука в концтаборі Бухенвальд. Ось так Сол Беллоу подає один iз жахливих епізодів життя в концтаборі: «...to Bruch's Buchenwald reminiscences. ...And then a man fell into the latrine trench. No one was allowed to help him, and he was drowned there while the other prisoners were squatting helpless on the planks. Yes, suffocated in the feces» $[6, \mathrm{p} .58]$.

Подібні психічні травми помножуються безоднею забуття, на краю якої стоять старі. Артур Семмлер розмірковує про вибіркову природу «історичної пам'яті»: «If you considered what the historical memory of mankind would retain, it would not bother to retain the Bruchs; nor, come to that, the Sammlers. Sammler didn't much mind his oblivion, not with such as would do the remembering, anyway. He thought he had found out the misanthropy of the whole idea of the "most memorable". It was certainly possible that the historical outlook made it easier to dismiss the majority of instances. In other words, to jettison most of us» [6, p.62]. Безумовно, що він ідейно наполягає на тому, що травмована пам'ять виживших має долати інертність суспільства, вимагати «бути почутим» [6]. Це не просто забаганка старих - Семмлер розуміє, що злочинці радіють забуттю («замітають сліди»), а жертви навпаки зберігають 
«сліди». Це відбувається в дзеркальній симетрії - забуття захищає злочинця та послаблює жертву [6].

Та старіння Семмлера має й менш «глобальні» аспекти. Сол Беллоу яскраво демонструє наполегливу віру в ідеали «минулого» всупереч динамічному сьогоденню. Наскрізною сюжетною лінією роману є протистояння одіозного автобусного крадія та Семмлера. Старий вперто бажає «покарати» злочинця, хоча має до нього суперечливі почуття. У впорядкованому моральному кодексі старого крадіжка має бути покарана. Письменник комічно ілюструє марні намагання Семмлера знайти дієвий відклик у американської поліції. Він розуміє безперспективність цих спроб, але це його не зупиняє - постійні дзвінки у відділок поліції демонструють повне нерозуміння Семмлером механізмів системи правопорядку великого американського міста. Він «застряг» у минулому, екстраполює досвід «старої доброї довоєнної Європи» на криміногенний Нью-Йорк.

Та письменник не просто кепкує зі старого - він просто розводить різні історико-культурні шари в окремі самодостатні одиниці, що не перемішуються. Сол Беллоу тривожно підмічає, що порядність та щирість стають рудиментами в сучасному суспільстві, що неповага до власності, заохочування нахабства та боягузтво перед зухвалим грабіжником притаманні самозосередженним нью-йоркцям. Семмлер виступає своєрідним Дон-Кіхотом - таким саме «останнім романтиком» серед байдужо-ворожого середовища. Подібне ми спостерігали в романі «Герцог» - там головний герой також постійно балансував на грані нормальності, оскільки не завжди вмів інтегруватися в суспільні схеми. Цікаво, що в «Дарі Гумбольдта» Сол Беллоу вже робить ще тонкіші грані між екзальтованими напівбожевільними і «нормальними» героями. Подібна розстановка акцентів дозволяє письменнику досягати цікавих комбінацій симпатій / антипатій, що часто виглядають абсурдно та провокативно.

Архаїка моралі людей похилого віку також цікавила й Юрія Трифонова - в «Обміні» найяскравішим іiі представником 
був дід головного героя, Федор Миколайович Дмитрієв, що уособлював собою «відблиск багаття» I чверті XX ст. Письменник зображує його в рамках марних пошуків «останніх моральних авторитетів» радянського суспільства. Але вірність правді Юрію Трифонову диктувала зобразити «досвідченого революціонера» ((який «сидів» як при царі, так (по деяким натякам) і в сталінські часи)) чудернацьким уламком минулого. Вже в повісті «Інше життя» Трифонов розкриває природу подібного «дивацтва» - вірна ідеалам «старих більшовиків» бабця Олександра Прокопівна обіцяє внучці гроші на зимові чоботи, але не віддає їх, бо та хоче купити їх «у спекулянтів» ((реалії радянського життя - офіційно в магазині за зазначеною ціною придбати якісне взуття (як і багато чого іншого) було неможливо)). Подібна «чесність» сприймається іншими героями повісті як вияв повної відірваності від реального життя, що давно протікає за усталеними подвійними стандартами.

Піковим для усвідомлення своєї старості для Семмлера стає лекція в університеті - наприкінці іiі він піддається повній обструкції. Та болісні провокативні слова радикальних представників студіюючої молоді мають допомагають Семмлеру краще усвідомити свою відірваність від теперішнього життя. Він опинився в ситуації, коли люди вже одягаються «поіншому», вживають інший лексикон і часто не розуміють слів «з минулого». Для молоді він - рудимент, що тягне за собою шлейф спогадів. Семмлер усе ще сподівається трансформувати ці спогади в цінний матеріал, але йому все важче знайти для цього правильні форми. Та Беллоу не поміщає Семмлера в інформаційний вакуум - $\epsilon$ низка людей, що виявляють живий інтерес до спогадів старого. Вони допомагають йому відчути себе «людиною». Парадоксально, але й критики та недоброзичливо налаштовані люди також допомагають Артуру Семмлеру долати травматичну пам'ять. Роль негативно налаштованих людей полягає у збереженні зацікавлення «персоною Семмлера». Брутальний крадій чи агресивний студент своїми вчинками на сторінках роману ніби кажуть Семмлеру - «ти живий», «ти існуєш» тощо. 
Тобто увага трансформується в цінність, що важлива для подолання руйнівної сили «відсутності уваги до себе». Цей психологічний шар тонко помітив ще Жан-Поль Сартр у романі «Нудота» - доктор Роже називає Ахіля образливими словами, але це має функцію «оздоровлення» старого, допомагає йому «протриматися ще один день». Старий намагається зробити все, щоб лікар звернув на нього свою увагу: «Лікар кладе свої грубезні руки на стіл і хапається за закраїни. Пан Ахіль аж світиться від щастя, йому дуже хочеться, щоб лікар звернув на нього увагу. Але намарно він гойдає під столом ногою та врядигоди підстрибує на стільці - він такий малий, що не в змозі порушити тишу [5, с.70].

Сартр ілюструє добирає яскравих фарб у поведінку лікаря. Гра в «шанобливе суспільство» замінюється грою «в поганих хлопців»:

«- А-а, це ти, старий покидьку! - вигукує він. - Як, ти ще не здох? - I тепер уже до офіціантки: - Ви пускаєте це одоробло до себе? - Своїми хижими очима він їсть маленького чоловічка. Погляд гострий і прямий, погляд, що все ставить на свої місця.

- Це ж старий варіят, хіба ви не бачите!

Він не завдає собі навіть труду показати, що жартує. Лікар знає: старий варіят не сердитиметься на нього й у відповідь буде лише усмішка. Так і $\epsilon$-скривджений принижено всміхається. Старий варіят відчуває полегшення, ніби його оборонили від нього самого і сьогодні йому нічого не станеться. Але найбільше вражає те, що я теж заспокоївся. A-a, мовляв, так це старий варіят, а я гадав...» [5, с.70].

У Сола Беллоу Артур Семмлер зазнає ще більш нищівної критики: ““Orwell was a fink. He was a sick counterrevolutionary. It's good he died when he did. And what you are saying is shit." Turning to the audience, extending violent arms and raising his palms like a Greek dancer, he said, "Why do you listen to this effete old shit? What has he got to tell you? His balls are dry. He's dead. He can't come". Sammler later thought that voices had been raised on his side. Someone had said, "Shame. Exhibitionist." But no one 
really tried to defend him. Most of the young people seemed to be against him. The shouting sounded hostile. Feffer was gone, had been called away to the telephone. Sammler, turning from the lectern, found his umbrella, trench coat, and hat behind him and left the platform...» $[6, \mathrm{p} .42-43]$.

Та у Сартра критика все ж містить «лікувальний елемент», вона спрямована все ж ще «потішити старого», надати йому чудернацьку розраду. При цьому старий та лікар знаходяться в межах суспільної системи, лікар навіть виконує функцію, що несуть також священики, урядовці, офіцери. Цю функцію Сартр зводить до Досвіду, що має превалювати над об'єктивним спостереженням світу. Досвід допомагає легко маніпулювати людьми: «Пан Ахіль, мабуть, давно вже не був такий щасливий, як сьогодні, - в нього просто не стуляється рот iз захвату... А й хвацько ж присадив його лікар! Лікаря не загіпнотизувати цим істеричним виглядом старого варіята; добра прочуханка, кілька брутальних слів, - оце й усе, що треба таким. Лікар має досвід. Одразу знати професіонала; всі ці лікарі, священики, урядовці, а також офіцери знають людську душу так, ніби самі сотворили людину» [5, с.70].

Проте Беллоу полишає Семмлера в більш разючих обставинах - травматичний досвід приніс відсутність віри в гуманізм та посилив сплутаність свідомості. Артур Семмлер навіть не може очікувати співчуття - йому доводиться його «вигадувати».

Подібні обставини притаманні «сучасній Америці». В цій системі люди зосередженні на досягненні особистого успіху, що заважає їм подекуди звертати увагу на проблему інших. Сол Беллоу дуже критикує США в своїх творах - інколи стилістика його роздумів наближається за гостротою до супротивників Америки. Та він все ж є прибічником свободи і демократії американського суспільства. Саме цей рівень демократії дозволяє письменнику відкрито висловлювати свою думку, критикувати недоліки суспільства та сприймати дійсність «без прикрас». Артур Семмлер відчуває надзвичайне піднесення від можливості називати себе «американцем XX століття»: «And the 
charm, the ebullient glamour, the almost unbearable agitation that came from being able to describe oneself as a twentieth-century American was available to all» [6, p.75]. Він вважає, що знаходиться в потужному емоційному та інтелектуальному потоці Нью-Йорку. В цьому місті зосереджена колосальна кількість дієвих особистостей, що становлять собою оригінальну спільноту. Місто становить собою джерело потужної енергетики - позитивної та негативної. Вона дозволяє загоїти рани травматичної пам'яті, абстрагуватися від негативного досвіду минулого.

Семмлер аналізує кипуче життя Нью-Йорку з позиції стороннього спостерігача. Більше того він дає вражаючу характеристику цьому місту, ставлячи його в ряд інших великих мегаполісів: "Great cities are whores. Doesn't everyone know? Babylon was a whore... Penicillin keeps New York looking cleaner. No faces gnawed by syphilis, with gaping nose holes as in ancient times...» [6, p.163]. Фактично велике місто становить собою арену суцільної травми - динамічний темп життя суттєво впливає на внутрішній стан людей. Багато 3 них опиняються розчавленими шаленою динамікою розвитку, втрачають орієнтири та виплескують назовні наслідки свого спотворення: "You had to be strong enough not to be terrified by local effects of metamorphosis, to live with disintegration, with crazy streets, filthy nightmares, monstrosities come to life, addict's, drunkards, and perverts celebrating their despair openly in midtown» [6, p.74].

Та все ж найтравматичнішою зображена війна. Сол Беллоу чітко відокремлює людей, що пережили війну, та «інших». Стан людини, що пережила війну, письменник детермінує у якості «не зовсім людина» («For quite a long time he had felt that he was not necessarily human» [6, p.117]). Тобто, особистість набуває унікальних якостей - вони необхідні для виживання в екстремальних умовах, для боротьби і рішучих дій. Але вони обтяжують особистість у повсякденному повоєнному житті.

Трагізм військового досвіду через деякий час зменшив тиск на свідомість Артура Семмлера. Дивовижно, але рішенням 
цієї проблеми виступили просто «звичайні людські речі», побутові «дрібниці» та «маленькі земні радощі». Похований живцем, Семмлер ніби довгий час собі відмовляв у праві «просто жити». Та травматизм був витіснений саме співвідношенням часу та «звичайного побуту»: «But then, ten or twelve years after the war, he became aware that this too was changing. In the human setting, along with everyone else, among particulars of ordinary life he was human - and, in short, creatureliness crept in again» [6, p.117].

Голокост та єврейська ідентичність не є для Сола Беллоу основною темою, але без неї він не може обійтися у своїх творах, оскільки картина оточуючого світу була б неповною. Тема належності до єврейства супроводжує головних i другорядних героїв твору, додає яскравих емоцій та часто відтворює комічні й трагічні сторони життя євреїв у різних країнах. Сол Беллоу сміливо розставляє акценти та доводить реальність антисемітизму в обоймі ксенофобій минулого та сучасного.

Головні герої творів Сола Беллоу, як правило, є євреями - він пише про те, що знає. I не просто євреї - американські євреї, що здебільшого втратили стійкі межі автентичності, свідомо чи в силу різних обставин адаптувалися до «нового суспільства». Втрата зв'язку з історичним корінням у багатьох призвів до травматичних наслідків - свідомість не зуміла компенсувати національних традицій та причетності до спільноти «одновірців». Відхід від «батьківських і дідівських» форм життя Артур Семмлер спочатку сприймав позитивно - для нього це був міраж інтелектуальної свободи, що зазнав нищівного краху в роки війни. Виявилося, що він пов'язаний із своїм народом невидимими нитками, за цими ознаками він розглядається здебільшого оточуючим світом i за цими факторами сприймає оточуючий світ.

Саме коріння часто допомагає віднайти себе людині в буремні часи. Особливо це актуально коли людина опиняється відкинутою «системою», коли «система» маркує людину як «чужу». При цьому, знаходячись «у системі», людина може не 
звертати увагу на свою національну приналежність. Але травматична пам'ять часто концентрується на архетипах спогадів, що своїм корінням сягають «сивої давнини». Подібну трансформацію свідомості пережив поет Олександр Галич. Він так «сформував» цей процес у своєму вірші:

Вспомни:

На этих дюнах, под этим небом, Наша - давным-давно - началась судьба. С пылью дорог изгнанья и с горьким хлебом, Впрочем, за это тоже:

- Тогда раба!

Только

Ногой ты ступишь на дюны эти, Болью - как будто пулей - прошьет висок,

Словно из всех песочных часов на свете Кто-то - сюда веками - свозил песок!

Видишь - Уже светает над краем моря, Ветер - далекий благовест - к нам донес, Волны подходят к дюнам, смывая горе, Сколько - уже намыто - утрат и слез?!

\section{Сколько}

Утрат, пожаров и лихолетий?

Скоро ль сумеем им подвести итог?!

Помни -

Из всех песочных часов на свете Кто-то - сюда веками - свозил песок!

Артур Семмлер тільки частково «повернувся» до єврейського коріння. Та він відкидає вже зневажливе ставлення до коріння, як до «селянського пережитку». Та в умовах заплутаної свідомості, що містить чимало травматичного досвіду, орієнтир на національність часто залишається одним із найбільш ясних і прозорих. Щоправда, він часто губиться в розрізі віри, оскільки Сол Беллоу не полишає глибоких роздумів про необхідність обирати той чи інший шлях. Поведінка Шули 
(доньки Семмлера) подається в романі як елемент психічного розладу, спричинений травмами минулого. Її позмінна належність то до католицтва, то до іудаїзму зумовлена розладом особистості.

Протягом усього роману автор підводить читача до питання: «чи придатна наша планета до життя?». Жахливі випробування виявили занадто хижу людську природу, що не вписується в загальноприйняті рамки. Примітно, що Сол Беллоу «дозволив» побудувати Семмлеру «свою планету». Ця планета полягала у впорядкуванні свого внутрішнього світу. Саме такий висновок і робить автор - «розібратися в собі».

Висновки. Тільки вдумливе прочитання роману «Планета містера Семмлера» дозволяє виокремити проблему подолання травматичного минулого. Беллоу вдалося продемонструвати багатогранний досвід подолання негативних наслідків трагедій. Він сфокусував увагу на людині, що перетнула рубіж у 70 років. У цьому віці вже неможливо «не пережити» втрат і необхідно сформувати своє ставлення до них. Літературний персонаж лише частково може продемонструвати нам багатогранність механізмів пам'яті, особливо травматичної.

Історико-культурний контекст створює необхідні умови для розуміння тих чи інших обставин становлення, формування, розвитку та занепаду чинників, що впливають на «довгі тіні минулого». Саме контекст заміняе собою почасти поняття «пам'яті», оскільки пам'ять людини в своїй біологічній природі принципово відрізняється від пам'яті нації, пам'яті суспільства та навіть пам'яті родини. Деякі механізми є спільними між індивідуальною і колективною пам'яттю, деякі - відмінні. Але саме контекст дозволяє більш точно дослідити самий цікавий $\mathrm{i}$ дієвий пласт подолання минулого у взаємодії колективних та індивідуальних спогадів. Сол Беллоу майстерно це зобразив за допомогою моделювання конструювання минулого поряд iз свідомим і несвідомим аутентичним оригінальним «рухом живих спогадів». Безумовно, що ця тема ще довго буде актуальною та приваблюватиме дослідників із різних наукових галузей. 


\section{Література}

1. Братусь І.В., Кузьменко Г.В. Деякі культурно-історичні аспекти самоідентифікації особистості «інтелектуалів» у творах другої половини XX століття. Арт-платформа. Київ, 2020. №1. Cc. 39-68.

2. Братусь I.В., Свердлик 3.М., Гунька А.М. Значення історичної пам'яті в долі людини (на матеріалі романів «Старий» Юрія Трифонова та «Планета містера Семмлера» Сола Беллоу). Молодий вчений. 2020. №10. Сс. 449-452.

3. Бронич М.К. Сол Беллоу и Лев Толстой: уроки мастера. Вестник Вятского государственного университета, 2009. №2 (2), Cc. 174-179.

4. Механікова О. О. Жанрові особливості романів

С. Беллоу. Мировая литература на перекрестье культур и цивилизаций. 2012. №4. Сс. 193-199.

5. Сартр Ж-П. Нудота. Мур. Слова. Київ: Вид-во Соломії Павличко «Основи», 1993. 464 с.

6. Assmann A. Der lange Schatten der Vergangenheit: Erinnerungskultur und Geschichtspolitik. München: Verlag C.H. Beck. 2006.

7. Bellow S. Mr. Sammler's Planet. Delhi: UniversalBookStall, $1970.313 \mathrm{p}$.

8. Guttmann A., Bellow, S. Saul Bellow's Mr. Sammler. Contemporary Literature. 1973. Vol. 14(2). Pp. 157168.

9. Marshall A. 'Without Explaining': Saul Bellow, Hannah Arendt, and Mr. Sammler's Planet. The Cambridge Quarterly. 2011. Vol. 40. Issue 2. Pp. 141-160.

10. Parini J. Mr. Sammler, Hero of Our Time. Salmagundi. 1995. Vol. 106/107. Pp.66-70. 
Иван Викторович БРАТУСЬ, кандидат филологических наук, доцент, Киевский университет имени Бориса Гринченко,

Киев, Украина, e-mail: kulturolog@gmail.com, ORCID: 0000-0002-8747-2611

\title{
КУЛЬТУРНО-ИСТОРИЧЕСКИЙ КОНТЕКСТ ПРЕОДОЛЕНИЯ ТРАВМАТИЧЕСКОГО ПРОШЛОГО (НА ПРИМЕРЕ РОМАНА СОЛА БЕЛЛОУ «ПЛАНЕТА МИСТЕРА СЭММЛЕРА»)
}

\begin{abstract}
Аннотация. В данной статье проанализирован культурно-исторический контекст романа выдающегося американского писателя Сола Беллоу. В исследовании рассматривается вопрос преодоления травматического опыта главным героем произведения, его попытки избавиться от негативных последствий травмы на сознание и отчасти подсознание. Внимание уделяется также возрастной специфике главного героя, воспроизводятся особенности пожилых людей. Отдельно поднимается вопрос личной ответственности за правильность нравственного выбора в экстремальных жизненных условиях. Особое внимание уделяется периоду Второй мировой войны в разрезе травматических воспоминаний и неспособности человеческой психики усвоить преступную природу ужасных событий того времени. Также в фокусе исследования оказывается адаптация людей, переживших Холокост, в американском обществе в целом и в Нью-Йорке в частности. Актуальность исследования обусловлена нерешенностью многочисленных проблем исторической памяти, необходимостью углублять и расширять знания о травматической памяти и путях преодоления негативных последствий. Приводятся примеры несвободы от травматического прошлого, общего мемориального дискурса, динамики индивидуальной и коллективной памяти, морализации истории и актуализации систем против ползучего


универсального забвения. Автор останавливается на проблемах смерти, военного прошлого, Холокоста и т. п. Доказано, что в романе Сола Беллоу «Планета мистера Сэммлера» значительное место занимает анализ национальной идентичности в историкокультурном контексте XX в. Выполнен обзор основных событий биографии Артура Сэммлера с точки зори травматической памяти, неотступно преследует главного героя. Отдельно анализируется историко-культурный контекст американской действительности II пол. XX в. в целом и «жизнь Нью-Йорка» в частности. Делается соответствующая оценка событий ньюйоркской жизни в качестве «отвлекающих факторов» в преодолении травматической памяти. Приведены концепции баланса между памятью и забвением. Предоставлены убедительные аргументы в пользу правильного конструирования прошлого с позиции жертвы, соответственно необходима консервация следов нацистских преступлений ради ослабления разрушительной силы забвения на личность жертв. Победа жертвы видится в артикуляции травмированной памяти, извлечении ее из «непрозрачного ядра» (подсознания). При этом отстаивается позиция Артура Сэммлера в борьбе против «систематической лжи».

Ключевые слова: Сол Беллоу, американская литература, война, травматическая память 
Ivan V. BRATUS,

$\mathrm{PhD}$ in Philology, Associate Professor,

Borys Grinchenko Kyiv University,

Kyiv, Ukraine,

e-mail: kulturolog@gmail.com,

ORCID: 0000-0002-8747-2611

\title{
CULTURAL AND HISTORICAL CONTEXT OF OVERCOMING THE TRAUMATIC PAST (ON THE EXAMPLE OF SAULL BELLOW'S NOVEL "MR. SEMMLER'S PLANE")
}

\begin{abstract}
The article analyzes the cultural and historical context of the novel by the outstanding American writer Saul Bellow. The study examines the overcoming of the traumatic experience by the protagonist of the novel, his attempts to get rid of the negative effects on consciousness and partly subconsciousness. Attention is also paid to the age specifics of the main character, which reproduces the characteristics of the elderly. The article raises the issue of personal responsibility for the correctness of moral choices in extreme living conditions. Particular attention is paid to the period of World War II in the context of traumatic memories and the inability of the human psyche to assimilate the criminal nature of the terrible events of that time. The study also focuses on the adjustment of Holocaust survivors to American society in general and to New York in particular. The relevance of the study is due to the unresolved problems of historical memory, the need to deepen and expand knowledge about traumatic memory and ways to overcome the negative consequences. Examples are given of the lack of freedom from the traumatic past, the general memorial discourse, the dynamics of individual and collective memory, the moralization of history and the actualization of systems against the creeping universal oblivion. The author dwells on the problems of death, the military past, the Holocaust and the like. It is proved that in Saul Bellow's novel "The Planet of Mr. Sammler" the analysis of national identity in the historical and cultural context of the twentieth century
\end{abstract}


occupies a significant place. The main events of Arthur Sammler's biography are reviewed from the point of view of the traumatic memory that persistently haunts the main character. The historical and cultural context of American reality in the second half of the twentieth century in general and "life in New York" in particular is analyzed separately. An appropriate assessment of the events of New York life as "distractions" in overcoming traumatic memory is provided. The balance between memory and oblivion is given. Arguments in favor of attempts to construct the past from the position of a victim of Nazi crimes are presented. Victory is seen in the articulation of traumatized memory, the removal of memories from the subconscious to the consciousness. At the same time, the position of Arthur Sammler in the fight against "systematic lies" is defended.

Key words: Saul Bellow, American literature, war, traumatic memory

\section{References}

1. Bratus, I.V., Kuzmenko, H.V. (2020). Deyaki kul'turnoistorychni aspekty samoidentyfikatsiyi osobystosti «intelektualiv» $\mathrm{u}$ tvorakh druhoyi polovyny XX stolittya. [Some cultural and historical aspects of self-identification of the personality of "intellectuals" in the works of the second half of the twentieth century]. Art-platforma. 1, 39-68 [in Ukrainian].

2. Bratus, I., Sverdlyk, Z., Gunka, A. (2020). Znachennya istorychnoyi pam"yati v doli lyudyny (na materiali romaniv "Staryy" Yuriya Tryfonova ta "Planeta mistera Semmlera" Sola Bellou) [The significance of historical memory in human destiny (based on the novels "The Old Man" by Yuri Trifonov and "The Planet of Mr. Semmler" by Solo Bellow)]. Molodyi vchenyi, 10, 449-452 [in Ukrainian].

3. Bronich, M. (2009). Sol Bellou i Lev Tolstoy: uroki mastera [Sol Bellow and Leo Tolstoy: Lessons from a Master]. Vestnik Vyatkskogo gosufartvennogo univrsiteta, 2 (2), 174-179 [in Russian]. 
4. Mehanikova, O. (2012). Zhanrovi osoblyvosti romaniv S.Bellou [Genre features of S. Bellow's novels]. Mirovaya literatura na perekrest'ye kul'tur i tsivilizatsiy, 4, 193-199 [in Russian].

5. Sartr, Zh.-P. (1993). Nudota. Mur. Slova. [Nausea. Wall. Words.]. Kyiv: Vid-vo Solomíi Pavlychko "Osnovy” [in Ukrainian].

6. Assmann, A. (2006). Der lange Schatten der Vergangenheit:

Erinnerungskultur und Geschichtspolitik. München: Verlag C.H. Beck [in German].

7. Bellow, S. (1979). Mr. Sammler'sPlanet. Delhi: Universal Book Stall [in English].

8. Guttmann, A., Bellow, S. (1973). Saul Bellow's Mr. Sammler. Sovremennaya literatura, 14(2), 157-168 [in English]. 9. Marshall, A. (2011). 'Without Explaining': Saul Bellow, Hannah Arendt, and Mr. Sammler's Planet, The Cambridge Quarterly, 40, 2, 141-160 [in English].

10. Parini, J. (1995). Mr. Sammler, Hero of Our Time. Salmagundi, (106/107), 66-70 [in English]. 